\title{
Review Article \\ The Biological and Metabolic Fates of Endogenous DNA Damage Products
}

\author{
Simon Wan Chan ${ }^{1}$ and Peter C. Dedon ${ }^{1,2}$ \\ ${ }^{1}$ Department of Biological Engineering, Massachusetts Institute of Technology, NE47-277, Cambridge, MA 02139, USA \\ ${ }^{2}$ Center for Environmental Health Sciences, Massachusetts Institute of Technology, Cambridge, MA 02139, USA \\ Correspondence should be addressed to Peter C. Dedon, pcdedon@mit.edu
}

Received 14 September 2010; Accepted 31 October 2010

Academic Editor: Ashis Basu

Copyright (C) 2010 S. W. Chan and P. C. Dedon. This is an open access article distributed under the Creative Commons Attribution License, which permits unrestricted use, distribution, and reproduction in any medium, provided the original work is properly cited.

DNA and other biomolecules are subjected to damaging chemical reactions during normal physiological processes and in states of pathophysiology caused by endogenous and exogenous mechanisms. In DNA, this damage affects both the nucleobases and 2-deoxyribose, with a host of damage products that reflect the local chemical pathology such as oxidative stress and inflammation. These damaged molecules represent a potential source of biomarkers for defining mechanisms of pathology, quantifying the risk of human disease and studying interindividual variations in cellular repair pathways. Toward the goal of developing biomarkers, significant effort has been made to detect and quantify damage biomolecules in clinically accessible compartments such as blood and and urine. However, there has been little effort to define the biotransformational fate of damaged biomolecules as they move from the site of formation to excretion in clinically accessible compartments. This paper highlights examples of this important problem with DNA damage products.

\section{Introduction}

Endogenous processes of oxidative stress and inflammation cause DNA damage that is mechanistically linked to the pathophysiology of cancer and other human diseases [1]. The DNA damage is comprised of dozens of mutagenic and cytotoxic products [2-4] reflecting the full spectrum of chemical mechanisms, including oxidation, nitrosation, halogenation, and alkylation, as described in numerous published reviews [5-15]. There has been significant interest in developing DNA damage products as biomarkers of disease risk given the strong association between DNA damage and disease pathology $[12,14,16-22]$. However, there has been little consideration given to the biological fate of DNA damage products, such as release from DNA as a result of instability, repair, and reaction with local nucleophiles, and the effect of this fate on the steady-state level of DNA lesions in cells and tissues. Further, the use of tissue-derived DNA for biomarker development poses the problem of accessibility and limits clinical studies, so researchers are exploring the presence of
DNA damage products in other sampling compartments, such as urine (e.g., [16, 23]). These efforts have presumed that DNA repair or cell death leads to dissemination of DNA damage products in blood, with subsequent excretion of specific molecular forms predicted to arise from the various DNA repair or other enzymatic processes. However, one of the major drawbacks to the use of blood or urine as a sampling compartment for development of DNA damage products as biomarkers is the lack of mechanistic information about the fates of the damage products in terms of metabolism and distribution. While information about the metabolic fate and pharmacokinetics of drugs based on nucleobases has been well defined (e.g., $[24,25]$ ), studies of the metabolism of DNA damage products have been limited to a few products such as adducts of ethylene dibromide [26], the pyrimidopurinone adduct of $\mathrm{dG}, \mathrm{M}_{1} \mathrm{dG}$ [27-29], and the base propenal and butenedialdehyde species arising from 2deoxyribose oxidation in DNA [30-32].

The mechanisms governing the fate of endogenous DNA damage products can be viewed from two perspectives, 
the first being local reactions that lead to the release of the damage product, such as chemical instability or DNA repair, or the reaction of electrophilic damage products with local nucleophiles. The second perspective is that of drug and xenobiotic metabolism and distribution. In both cases, the release of the damage products from DNA results in their diffusion or transport into extracellular space for subsequent distribution in the blood circulation to the liver and excretory organs. Chemical stability governs the extent and form of distribution of the damage product, with electrophilic species reacting with local nucleophiles and more stable products circulating throughout the body. The damage products may be recognized as substrates for the variety of local or distant metabolic enzymes that cause oxidation, reduction, hydrolysis, and conjugation (e.g., glucuronic acid, sulphate, or glutathione), with metabolites excreted in either urine or bile $[33,34]$. We can also view DNA damage products from the perspective of metabolic toxification and detoxification. Metabolic reactions are well known to either reduce the activity of reactive and toxic xenobiotics or to convert unreactive molecules to reactive intermediates that are genotoxic, hepatotoxic, or nephrotoxic [33, 34]. This paradigm applies to DNA damage products that range from relatively stable (e.g., nucleobase deamination products) to highly electrophilic (e.g., base propenals from 2-deoxyribose oxidation in DNA), with metabolic reactions occurring in cells in which the DNA damage occurs or in the liver or other metabolic tissues.

This review addresses the current state of understanding of the metabolic and biological fates of DNA damage products, with an eye on the implications of these fates for mechanisms of toxicity and for development of biomarkers of oxidative stress and inflammation.

\section{The Spectrum of Nucleic Acid Damage Products}

As a prelude to understanding the biological fate of damaged nucleic acids, we must first consider the spectrum of damage products. Nucleobases in DNA, RNA, and the nucleotide pool are subject to damage by a variety of chemical mechanisms related to normal and pathological processes. The superoxide $\left(\mathrm{O}_{2}{ }^{\cdot-}\right)$ and hydrogen peroxide $\left(\mathrm{H}_{2} \mathrm{O}_{2}\right)$ generated during aerobic respiration participate in Fenton chemistry to produce hydroxyl radical $\left(\mathrm{HO}^{\bullet}\right)$, while the activated macrophages and neutrophils of chronic inflammation generate a host of chemically reactive species, including the oxidants peroxynitrite $\left(\mathrm{ONOO}^{-}\right)$and nitrosoperoxycarbonate $\left(\mathrm{ONOOCO}_{2}{ }^{-}\right)$, hypohalous acids $(\mathrm{HOCl}, \mathrm{HOBr})$, and nitrosating agents $\left(\mathrm{N}_{2} \mathrm{O}_{3}\right)$ [8]. Damage to nucleic acids and nucleotides can occur by direct reaction with these agents or indirectly by reaction with electrophiles generated during oxidation of lipids, carbohydrates, and proteins. Both the nucleobase and sugar moieties are susceptible to attack, with examples of nucleobase damage products shown in Figure 1 and 2-deoxyribose oxidation products shown in Figure 2. The biological and metabolic fates of nucleobase damage products will be addressed first and that of 2-deoxyribose oxidation products later in this chapter.

\section{The Biological and Metabolic Fates of Damaged Nucleobases}

The biological fates of damaged nucleotides and nucleic acids can be viewed from the perspective of either the site of initial damage or from the final sampling compartment used for analysis of the damage products. Among the issues that arise are (1) the reactivity of a damage product and the chemical form of the lesion that is released from the site of generation; (2) the mechanism by which the released damage product reaches the systemic circulation; (3) the potential for the damage product to be chemically modified between the steps of formation and excretion; (4) the mechanism of excretion; (5) the potential for further chemical modification in the excretory compartment. The first of these issues, that of reactivity, is best illustrated by the susceptibility of 8-oxoguanine to further oxidation, as will be discussed shortly, and the deglycosylation of many damaged purines, such as 8-nitroguanine [8], and of purines subjected to $\mathrm{N}^{7}$-nitrosation or alkylation [8], both of which have been addressed in detail in the literature. Here we will focus on the metabolic fates of nucleobase damage products.

3.1. 8-Oxoguanine. The first consideration of the metabolic fate of a nucleobase damage product is the well-studied 7,8dihydro-8-oxoguanine (8-oxo-G; Figure 1) [35]. Perhaps the most comprehensive consideration of the biological fate of 8-oxo-G in terms of sources of 8-oxo-G-containing species excreted in the urine is the recent review by Cooke et al. [36], with a very recent review of the utility of 8-oxo-dG as a urinary biomarker [23]. Among the nucleobases in DNA, RNA, and the nucleotide pool, guanine is the most readily oxidized due to its favorable redox potential $[35,37-$ 39 ] with the spectrum of oxidation products depending on the nature of the oxidant $[8,35]$ (Figure 1). 8-Oxo$\mathrm{G}$ is one of the major products common to oxidation of guanine by most oxidizing agents, and it has thus been touted as a biomarker of oxidative stress (e.g., $[23,36$, $40,41]$. While oxidation of G in DNA is one source of 8-oxo-G, another involves polymerase incorporation of 8oxo-dGTP formed by oxidation of dGTP in the nucleotide pool [42]. Prokaryotes and eukaryotes are equipped with oxidized purine nucleotide di- and triphosphatases (e.g., E. coli MutT, 8-oxo-dGTP triphosphatase) to remove damaged nucleotides from the pool [43].

There are four fates of 8-oxoG in cellular DNA and nucleotides: further oxidation to more stable products, which will be discussed shortly, removal from DNA by repair mechanisms, removal from the nucleotide pool by nucleotide di- and triphosphatases, and eventual release from DNA following cell death. Like many nucleobase oxidation products, 8-oxo-G in DNA is removed by the base excision repair (BER) pathway [44-47], with the ultimate release of free 8-oxo- $\mathrm{G}$ nucleobase by $\mathrm{N}$-glycosylase activity. On the other hand, dephosphorylation of 8-oxo-dGTP and dGDP ultimately releases 8-oxo-dGMP and 8-oxodG, which are also the likely forms released from DNA following cell death. 


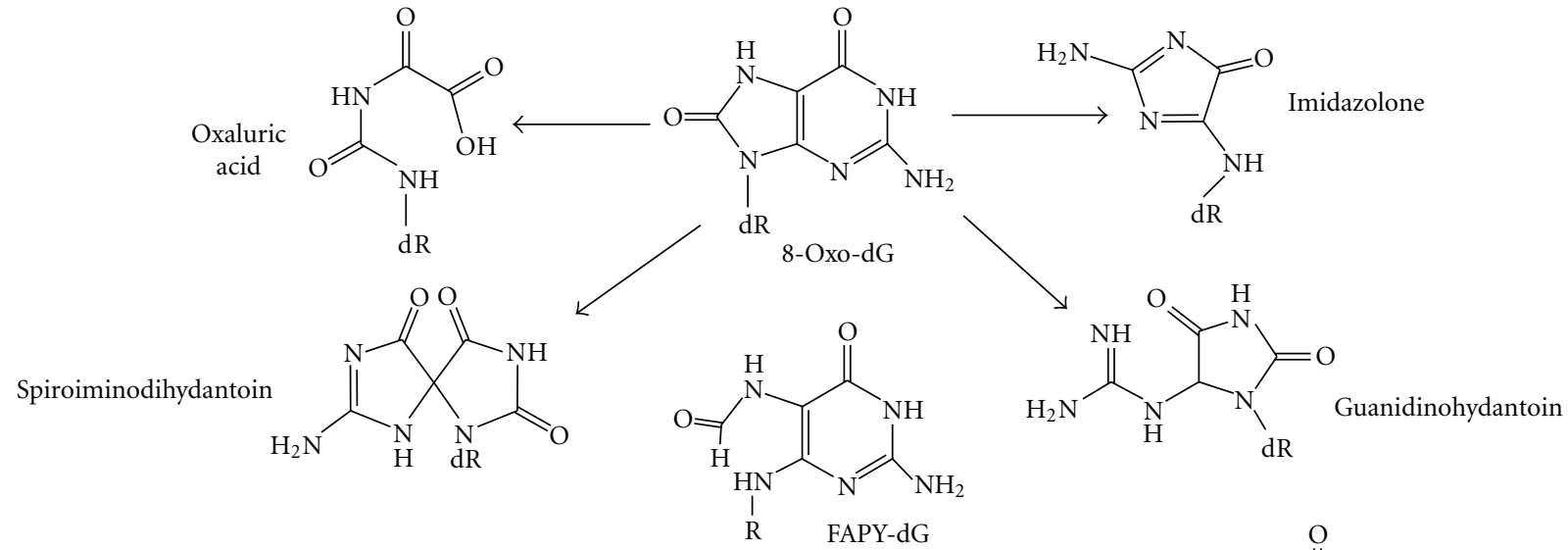<smiles>Nc1nc2c(nc([N+](=O)[O-])n2[AlH2])c(=O)[nH]1</smiles><smiles>N#CCNc1c([N+]#N)ncn1Br</smiles><smiles>[R]NC1=NC(N)(N)OC1=O</smiles><smiles>CCn1cnc2c(=O)n3cccnc3nc21</smiles><smiles>[R]c1cn(CCC)c(=O)[nH]c1=O</smiles><smiles>CCn1cnc2c(=O)[nH]c(=O)[nH]c21</smiles>
$2^{\prime}$-Deoxyuridine $2^{\prime}$-Deoxyanthosine<smiles>O=c1[nH]cnc2c1ncn2C1CCCCC1</smiles>

$2^{\prime}$-Deoxyuridine<smiles>Cn1cnc2c(=O)oc(N)nc21</smiles>

$2^{\prime}$-Deoxyanthosine<smiles>CCCCCC(=O)c1cnc2c3ncn(CCC)c3ncn12</smiles>
$\mathrm{A}, \mathrm{G}$, and $\mathrm{C}$<smiles>CCCCCCCCCCCCCn1cnc2c1ncn1c(CCCC)cnc21</smiles>

Heptanone eteno-adducts of A, G, and C<smiles>CCCn1ccc2ncc(C(C)C)n2c1=O</smiles><smiles></smiles>
$1, \mathrm{~N}^{2}$-Etheno-G $\left(1, \mathrm{~N}^{2}-\varepsilon \mathrm{G}\right)$<smiles>O=c1nc2[nH]ccn2c2c1ncn2C1CCCCC1</smiles>

Figure 1: Nucleobase damage products.

So, we are faced with the choice of quantifying either 8-oxo-G, 8-oxo-dG, or 8-oxo-dGMP in sampling compartments such as blood and urine. The most abundant of these species appears to be 8-oxo-dG, which is present in human urine at concentrations in the micromolar range. 2-Deoxynucleosides are chromatographically well behaved, and this concentration is amenable to precise and accurate quantification by liquid chromatography-coupled with mass spectrometric methods. While the excretion of 8-oxo-dG may correlate well with conditions of oxidative stress and inflammation [23], the source of this 8-oxodG has yet to be established.

Another fate of 8-oxoG in DNA, RNA, and the nucleotide pool, as well as the fate of 8-oxo-G-containing species released from cells, is further oxidation to form a variety of stable end products, as shown in Figure 1. 8-Oxo-G is significantly more susceptible to further oxidation than $G$ itself $(0.74 \mathrm{~V}$ versus $1.29 \mathrm{~V}$ relative to NHE [39]) and is thus susceptible to reaction with oxidants less potent than hydroxyl radical (2 V versus NHE), such as $\mathrm{NO}_{2}{ }^{\bullet}(1.04 \mathrm{~V}$ versus NHE [48]) and alkyl hydroperoxides $(\sim 0.9 \mathrm{~V}$ versus NHE [49]). The oxidation of 8-oxo-dG results in the formation of several new products (Figure 1), most of which are more stable than 8-oxo-dG itself and thus potentially better candidates for biomarkers of inflammation and oxidative stress. One must again consider the roles of DNA repair, nucleotide pool cleaning activities, and excretory pathways in finalizing the fate of 8-oxo-G oxidation products.

Finally, recent studies suggest two other confounding factors in the biological fate of 8-oxo-G. The first relates to 
(1)

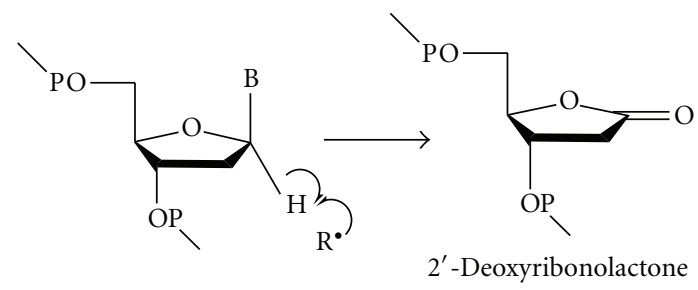

(2)
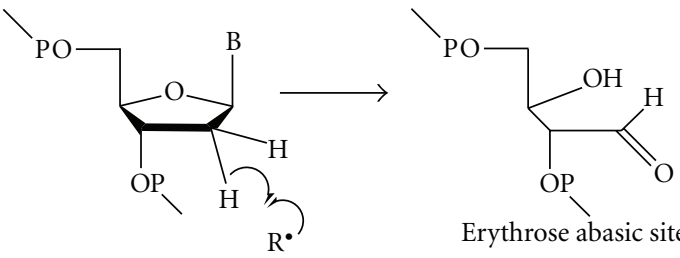

Erythrose abasic site

(3)

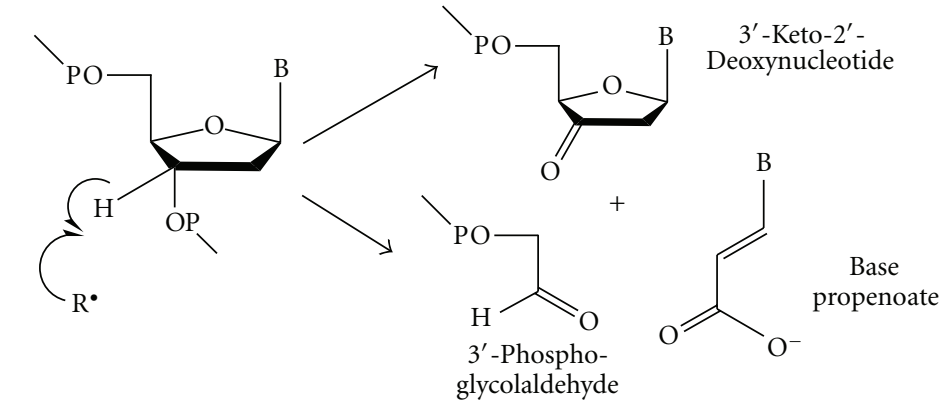

(4)

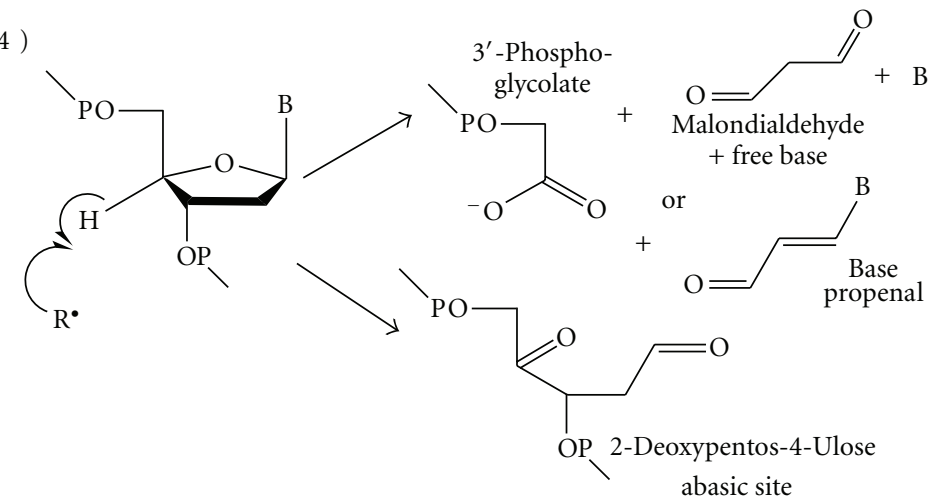

(5)

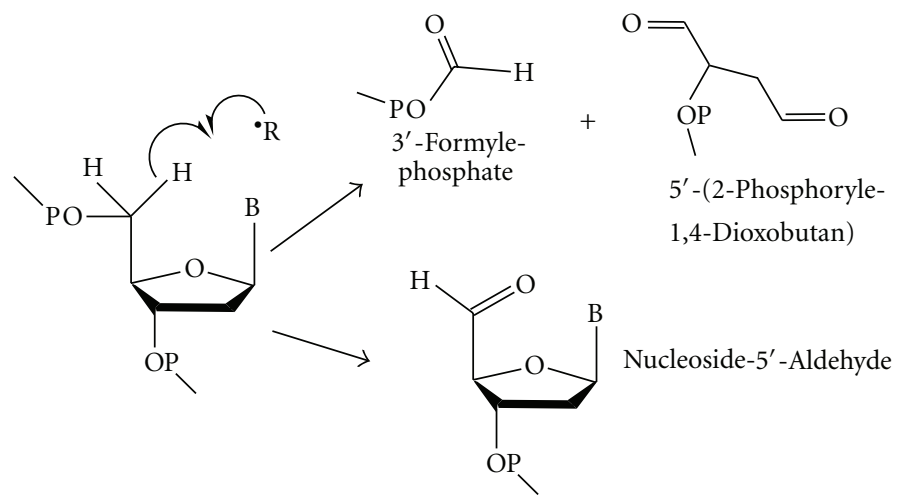

FIGURE 2: 2-Deoxyribose oxidation products. 
alternate sources. A study by Tannenbaum and coworkers reveals that 8-oxo-G can arise by further oxidation of species such as 8-nitro-G, which arises from nitrative oxidation of $\mathrm{G}$ by $\mathrm{ONOO}^{-}$and $\mathrm{ONOOCO}_{2}^{-}[50]$. This and other analogous chemistries further confound the assignment of the source of 8-oxo-G-containing species as mechanistic biomarkers. The second confounder involves an alternative fate for 8-oxo-G: deamination to uric acid. Hall et al. have described 8-oxo-G deaminase activity in bacteria [51], which raises the possibility of similar activities in human cells. While we have not observed adventitious deamination of $G$ in our studies of DNA deamination in vitro and in vivo [5255], a G deaminase activity cannot be ruled out.

3.2. Etheno Adducts. Another major group of DNA lesions with a well-established association with oxidative stress and inflammation involves adducts formed in the reaction of DNA with electrophiles generated by lipid peroxidation [5658]. This group includes the substituted and unsubstituted etheno nucleobase adducts [58-63] (Figure 1). Extensive study of the urinary excretion of unsubstituted etheno adducts has revealed a strong correlation of excretion with host of human diseases, pathologies, and environmental exposures related to oxidative stress (e.g., see recent studies in $[16-21,64])$. Nonetheless, there have been few if any studies aimed at defining the source of the etheno 2deoxynucleosides measured in these studies.

By analogy to 8 -oxo-G, the fate of etheno adducts can be viewed from the perspectives of DNA repair and metabolism. Etheno adducts in DNA are presumed to be repaired by the BER pathway [65], with the release of the free-base adducts. However, biomarker studies again focus on the 2-deoxynucleoside form of the adducts [16-21, 64], which must arise from pathways other than DNA repair. The current focus on quantifying etheno adducts as 2deoxynucleosides has recently been called into question by the Marnett group's pioneering studies of the metabolism of endogenous DNA adducts $[27-29,66]$. With regard to etheno adducts, they incubated 2-deoxynucleoside forms of substituted and unsubstituted etheno adducts in rat liver cytosol and observed an initial deglycosylation of G-derived etheno adducts followed by oxidation of $1, N^{2}-\varepsilon-G$ to $2-$ oxo-1, $N^{2}-\varepsilon-\mathrm{G}$ and of the corresponding substituted adduct, heptanone-1, $N^{2}-\varepsilon-G$, to 2-oxoheptanone-1, $N^{2}-\varepsilon-G$ (Figure 3) [66]. This raises the possibility that urinary biomarker studies may be underestimating the true level of etheno adducts as a result of loss of the 2-deoxynucleoside forms. Further, the oxidized free-base forms may also be useful as biomarkers if they are excreted at high enough levels.

3.3. $M_{1} d G$. This mutagenic pyrimidopurinone adduct of $d G$ (Figure 1) forms in reactions of DNA with the lipid peroxidation product, malondialdehyde, and with base propenals derived from $4^{\prime}$-oxidation of 2-deoxyribose in DNA [56, 67-72]. As an endogenous DNA adduct, $\mathrm{M}_{1} \mathrm{dG}$ has been detected at levels ranging from 1 to 1000 lesions per $10^{8}$ nucleotides in a variety of organisms, including humans $[67,71,73-79]$. Recent studies suggest that the major source of $\mathrm{M}_{1} \mathrm{dG}$ in vivo is base propenals from DNA oxidation [67],<smiles>CCn1c(=O)[nH]c2c(=O)n3cc[nH]c3nc21</smiles>

2-Oxo-1, $\mathrm{N}^{2}$-Etheno-G

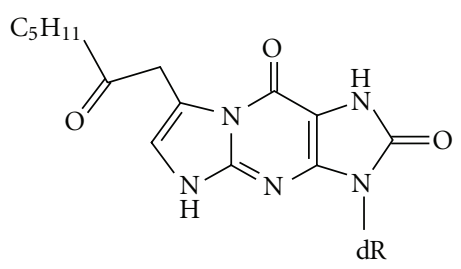

2-Oxo-heptanone-1, $\mathrm{N}^{2}$-Etheno-G

(2-Oxo-7-(2'-Oxoheptyl)-1, $\mathrm{N}^{2}-$

Ethenoguanine)

FIgURE 3: Oxidation of substituted etheno adducts.

which is consistent with the higher reactivity of base propenals than malondialdehyde $[68,69]$ and the proximity of base propenals to dG in DNA. However, contributions from both malondialdehyde and base propenals are likely to occur in an oxidant-, cell-, and tissue-dependent manner [72].

In terms of the biological fate of $\mathrm{M}_{1} \mathrm{dG}$, the adduct has been demonstrated to be a substrate for nucleotide excision repair (NER) [80, 81], which may explain the appearance of $\mathrm{M}_{1} \mathrm{dG}$ in human and rodent urine [27-29, 79]. However, $\mathrm{M}_{1} \mathrm{dG}$ was detectable in the human urine at levels of 10$20 \mathrm{fmol}$ per $\mathrm{kg}$ per $24 \mathrm{~h}$ [79], which is a significantly lower excretion rate than other DNA lesions such as 8-oxo-dG (400 pmol per kg per 24h) [82]. To explore the basis for this low rate of excretion, Marnett and coworkers undertook metabolic and pharmacokinetic studies of $\mathrm{M}_{1} \mathrm{dG}$ in rats [27]. When intravenously administrated to rats, $\mathrm{M}_{1} \mathrm{dG}$ was rapidly eliminated from the plasma with a half-life of $10 \mathrm{~min}$ [27]. In contrast to the rapid clearance from blood, $\mathrm{M}_{1} \mathrm{dG}$ was found in the urine for more than $24 \mathrm{hr}$ after dosing, which suggested a rapid distribution to tissue followed by slower phase of excretion. Analysis of the urine revealed a metabolite of $\mathrm{M}_{1} \mathrm{dG}$, 6-oxo- $\mathrm{M}_{1} \mathrm{dG}$, likely derived from hepatic xanthine oxidase activity [27]. Studies in rat liver extracts revealed further oxidation of 6 -oxo- $\mathrm{M}_{1} \mathrm{dG}$ on the imidazole ring to give 2,6-dioxo- $M_{1} G$ (Figure 4) [28]. While most of the $M_{1} d G$ was excreted unchanged in the urine and the problem of low levels of excretion remains unsolved, these studies point to the importance of defining the biological and metabolic fate of damaged biomolecules in efforts to develop biomarkers of inflammation and oxidative stress.

\section{The Biological and Metabolic Fates of 2-Deoxyribose Oxidation Products}

In addition to the nucleobases in DNA, the 2-deoxyribose moiety is also subjected to oxidative damage that merits consideration of biological fate and metabolism [9]. As opposed 
<smiles>O=CCC=O</smiles>

Malondialdehyde

(MDA)<smiles>O=C/C=C/O</smiles>

$\beta$-hydroxyacrolein

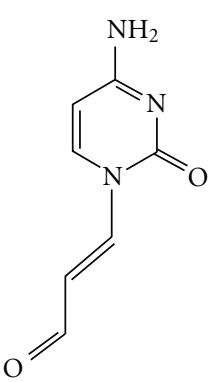

Cytosine propenal<smiles>CCn1cnc2c(=O)n3cccnc3nc21</smiles>

$\mathrm{M}_{1} \mathrm{dG}$<smiles>CCCn1cnc2c(=O)n3ccc(=O)[nH]c3nc21</smiles>

6-Oxo-M $\mathrm{M}_{1} \mathrm{dG}$<smiles>CCCn1c(=O)[nH]c2c(=O)n3ccc(=O)[nH]c3nc21</smiles>

2, 6-Oxo-M $\mathrm{M}_{1} \mathrm{dG}$

Figure 4: Formation and metabolism of $\mathrm{M}_{1} \mathrm{dG}$.

to the concept of simple "strand breaks," growing evidence points to 2-deoxyribose oxidation in DNA as a critical determinant of the toxicity of oxidative stress [9]. Oxidation of each of the five positions in 2-deoxyribose in DNA occurs with an initial hydrogen atom abstraction to form a carboncentered radical that rapidly adds molecular oxygen to form an unstable peroxyl radical. The resulting product spectra for 2-deoxyribose oxidation under aerobic conditions are shown in Figure 2 [9]. Many of these oxidation products are highly electrophilic, with $\alpha, \beta$-unsaturated carbonyl motifs, and are thus capable of reacting with proximate nucleophilic sites in DNA, RNA, and proteins to form adducts [9]. This section of the paper will focus on the biological and metabolic or, more broadly, biotransformational fates of 2-deoxyribose oxidation products.

4.1. DNA Adducts of 2-Deoxyribose Oxidation Products. One fate of DNA oxidation products is reaction with local electrophiles to form protein and nucleic acids adducts. In this regard, oxidation of 2-deoxyribose in DNA produces a variety of reactive electrophilic species (Figure 2) that readily form adducts with neighboring DNA bases. Oxidation of both the $2^{\prime}$ - and $3^{\prime}$-positions of 2-deoxyribose can lead to the formation of the 2-phosphoglycolaldehyde residue<smiles>Cn1cnc2c(=O)n3c(nc21)N[C@H](O)[C@H]3O</smiles><smiles>Cn1cnc2c(=O)[nH]c(NCC(=O)O)nc21</smiles>

Dihydroxy-1, $\mathrm{N}^{2}$-Ethano-G $\mathrm{N}^{2}$-(1-Carboxymethyl)-G<smiles>Cn1cnc2c(NC(=O)CO)ncnc21</smiles>

$\mathrm{N}^{6}$-(Hydroxyacetyl)-A<smiles>Cn1cc(C(=O)CO)c(N)nc1=O</smiles>

5-Hydroxyacetyl-C<smiles>O=C1c2nc[nH]c2N=C2[CH]N1N2[C@H]1CC[C@H](O)O1</smiles><smiles></smiles>

FIgURE 5: Glyoxal adducts of DNA.

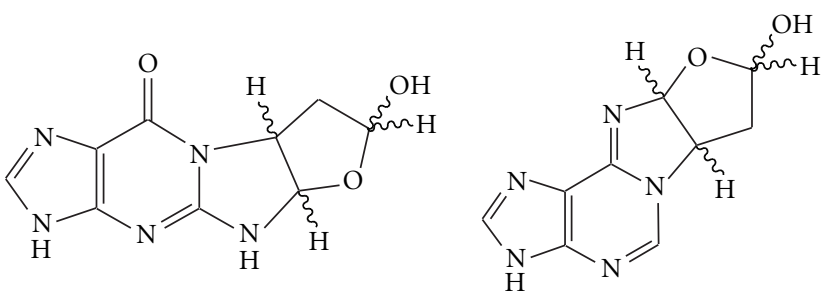

Figure 6: Reaction of 1,4-dioxo-2-butene to form bicyclic oxadiazabicyclo-(3.3.0) octaimine adducts.

(Figure 2), the latter directly from the oxidation $[83,84]$ and the former by an induced and indirect oxidation mechanism involving an erythrose intermediate [85, 86]. By either mechanism, 2-phosphoglycolaldehyde undergoes a relatively slow phosphate-phosphonate rearrangement to generate the ubiquitous lipid and carbohydrate oxidation product, glyoxal, that reacts with $\mathrm{dG}$ and DNA to form diastereomeric $1, \mathrm{~N}^{2}$-glyoxal adducts of dG (Figure 5) [83].

At the $4^{\prime}$ - and $5^{\prime}$-positions, $4^{\prime}$-oxidation generates base propenals that readily react with neighboring $\mathrm{dG}$ to form the pyrimidopurinone adduct, $\mathrm{M}_{1} \mathrm{dG}$, as described earlier [67-69]. Oxidation of the $5^{\prime}$-position leads to formation of a 2-phosphoryldioxobutane residue that, possibly following $\beta$-elimination to form an $\alpha, \beta$-unsaturated transdioxobutene species, reacts with $\mathrm{dC} \gg \mathrm{dG}>\mathrm{dA}$ to form bicyclic oxadiazabicyclo-(3.3.0)octaimine adducts (Figure 6) [87-91]. 


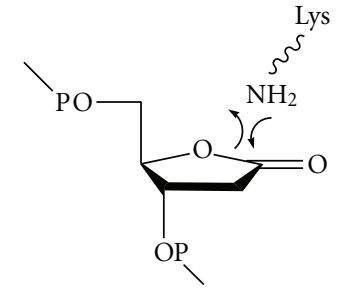

2-Deoxyribonolactone

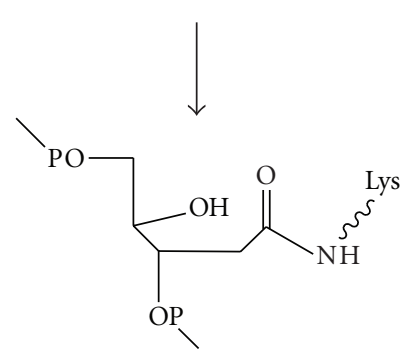

FIgURE 7: Formation of DNA-protein cross-links during repair of 2-deoxyribonolactone abasic sites in DNA.

4.2. Protein Adducts of 2-Deoxyribose Oxidation Products. In addition to DNA adducts, the electrophiles derived from 2-deoxyribose oxidation react with amino acid side chains in proteins to form a variety of adducts, some with functional consequences. One of the earliest examples of protein adducts from 2-deoxyribose oxidation involves the 1 '-position. The 2-deoxyribonolactone abasic site resulting from $1^{\prime}$-oxidation in DNA reacts with DNA repair proteins to form stable protein-DNA cross-links [92, 93]. This phenomenon was first demonstrated by Hashimoto et al. with the E. coli DNA BER enzyme endonuclease III [92]. This enzyme normally functions in base excision repair pathways with both an initial $\mathrm{N}$-glycosylase activity against oxidized pyrimidines and a subsequent incision of the resulting abasic site by a lyase activity [94]. Upon binding to the 2-deoxyribonolactone abasic site, however, the active site (lysine 120), which normally forms a Schiff base with the 1 -aldehyde in the ring-opened form of the native abasic site, performs a nucleophilic attack on the carbonyl group of the lactone ring (Figure 7). Unlike a Schiff base, the resulting cross-link is irreversible and complicates the DNA repair process [92]. DeMott et al. observed similar results in which a covalent amide bond was formed by the $1^{\prime}$ carbon of the lactone and the lysine 72 in human polymerase $\beta$ [93]. Additionally, the 2-deoxyribonolactone undergoes a rate-limiting $\beta$-elimination reaction to form a butenolide species with a half-life of $20 \mathrm{~h}$ in single-stranded DNA (32$54 \mathrm{~h}$ in duplex DNA), followed by a rapid $\delta$-elimination to release 5-methylene-2(5H)-furanone [95]. Both the intermediate butenolide and the product methylenefuranone are electrophilic species capable of reaction with nucleophilic sites in DNA and protein, and possibly subject to metabolic reactions such as glutathione conjugation.

Another potential source of protein adducts arises from the variety of $\alpha, \beta$-unsaturated carbonyl and dicarbonyl products of 2-deoxyribose oxidation in DNA. The potential here lies in the high concentration of nucleophilic lysine and arginine residues in histone proteins proximate to the sites of DNA damage and in the well-established reactivity of $\alpha, \beta$-unsaturated carbonyl and dicarbonyl species with nucleophilic amino acids, which is perhaps best illustrated by lipid peroxidation products (e.g., [96-103]. Several recent studies have identified specific lysine and histidine adducts of well-defined lipid peroxidation products such as malondialdehyde [100], 4-hydroxynonenal [99], and its oxidation product, 4-oxononenal [97] (Figure 8). The reactions forming these adducts are highly analogous to reactions that could occur with 2-deoxyribose oxidation products, as illustrated in Figure 8. For example, the unsaturated $\beta$-elimination product of the 2-deoxypentose4 -ulose product of $4^{\prime}$-oxidation of deoxyribose is a chemical analog of 4-oxononenal derived from lipid peroxidation. It would thus be expected to react with lysines and histidines in histone and other chromatin proteins to form the bisadduct or cross-link observed by observed by Sayre and coworkers [104] and the stable furan derivative observed by observed by Blair and coworkers [97], respectively (Figure 8). Indeed, histones 2A, 2B, and 3 contain 3-5 histidines that have been exploited to cross-link histones to DNA in the classic studies of Mirzabekov and coworkers [105, 106].

The malondialdehyde adducts of lysine, arginine, and histidine represent another protein adduct chemistry with potential parallels between 2-deoxyribose oxidation and lipid peroxidation. The reaction of lysine by nucleophilic substitution yields a moderately stable $\mathrm{N}$-propenal-lysine species (Figure 8) that can react with another lysine to form a propyl-bridged cross-link [107], while the reaction of malondialdehyde with arginine has been shown to produce a stable pyrimidyl-ornithine species (Figure 8) [107]. In both cases, the proportions of modified amino acids are high [108]. Given the analogous reactions of malondialdehyde and base propenals from $4^{\prime}$-oxidation, it is reasonable to expect the formation of propyl-bridged cross-links and pyrimidyl-ornithine species in histone proteins in cells subjected to oxidative stresses.

A final example of protein adducts derived from 2deoxyribose oxidation products involves $\mathrm{N}$-formylation of lysine by transfer of formyl groups from 3 '-formylphosphate residues (Figure 9) [109], among other possible sources such as oxidation of formaldehyde adducts of lysine. $\mathrm{N}^{6}$ formyllysine was detected in histone proteins from a variety of sources to the extent of $0.04 \%-0.1 \%$ of all lysines in acid-soluble chromatin proteins including histones, which suggests that the adduct represents an endogenous secondary modification of histones [109]. The chemical analogy of the $\mathrm{N}$-formyl modification to the physiologically important lysine $\mathrm{N}$-acetylation and $\mathrm{N}$-methylation suggests that lysine $\mathrm{N}$-formylation may interfere with signaling mediated by histone and other chromatin protein modifications (e.g., $[110,111])$.

In all of these cases, the adducted proteins are subject to degradation, with the potential for the release and excretion of adducted peptides or amino acids. Their potential as biomarkers warrants further study of DNA-derived protein adducts. 

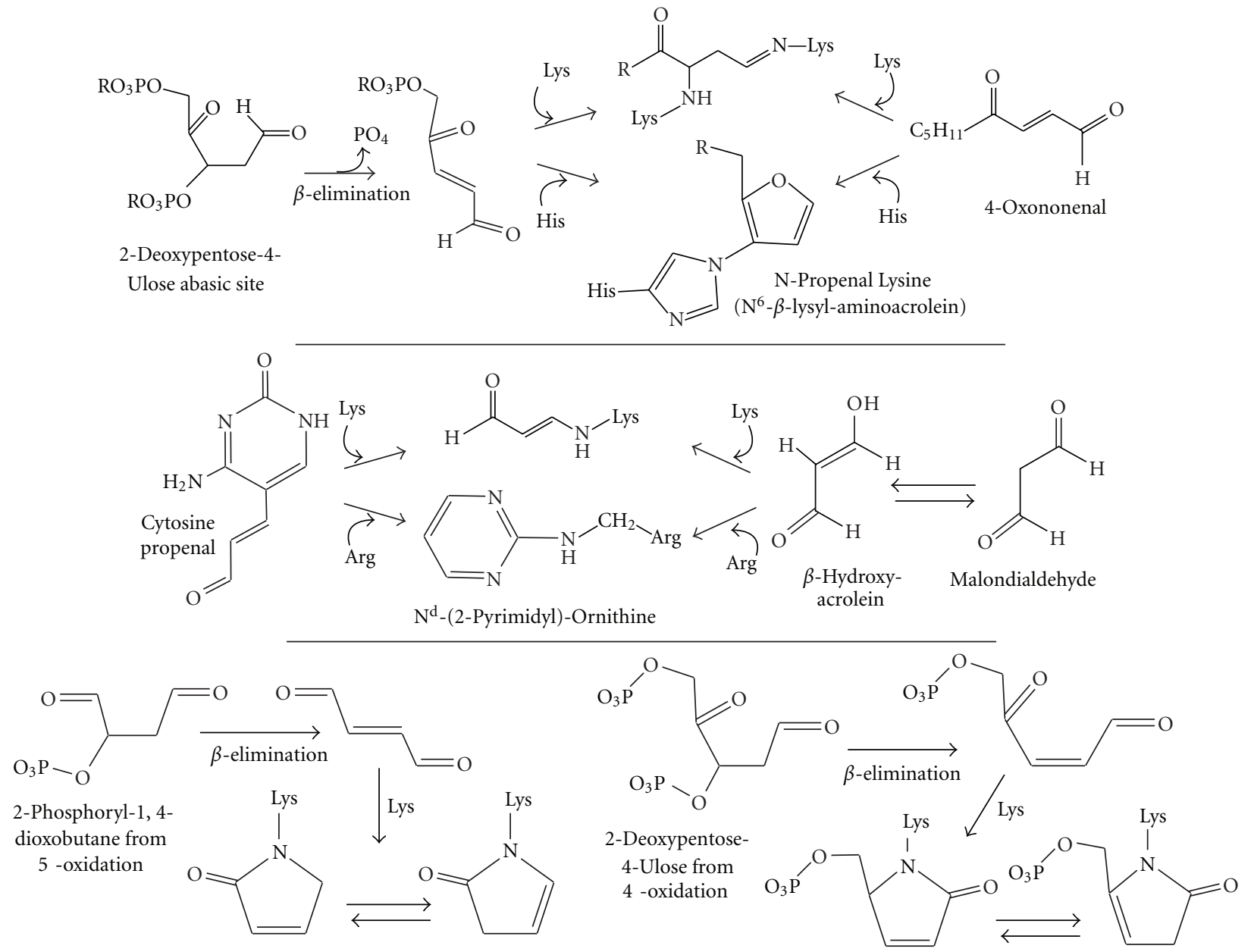

FIgURE 8: Reaction of lipid peroxidation products with lysine.

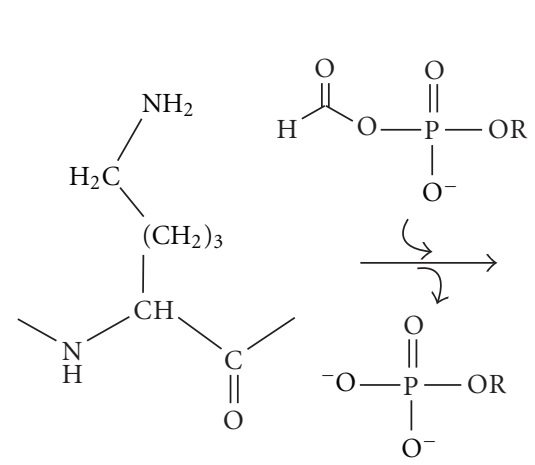

Lysine

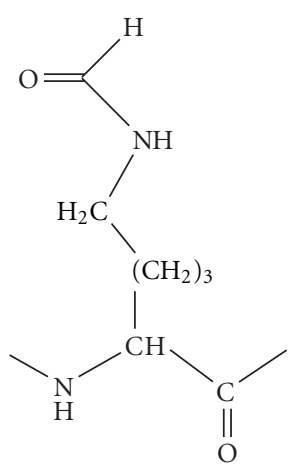

$\mathrm{N}^{6}$-Formyllysine
FIGURe 9: Lysine N-formylation by $3^{\prime}$-formylphosphate from $5^{\prime}$ oxidation of 2-deoxyribose.

4.3. Metabolism of 2-Deoxyribose Oxidation Products. As in the case of nucleobase lesions, the products of 2-deoxyribose oxidation of DNA must also be considered as substrates for metabolic enzymes and biotransformational reactions. This is all the more apparent given the electrophilic nature of the products, which points to glutathione (GSH) adduct formation, and the $\alpha, \beta$-unsaturated carbonyl structure of many of the products, which makes them ideal substrates for glutathione S-transferases (GST) [34]. Indeed, GSTs have been shown to react with $\alpha, \beta$-unsaturated aldehydecontaining lipid peroxidation products, many of which are chemical analogues of 2-deoxyribose oxidation products [9, 68]. Two examples of GST reactions with 2-deoxyribose oxidation products illustrate this biotransformation concept.

The first example involves GSH conjugation of base propenals. One of the classic definitions of GST substrates is that they must react directly with GSH to a measurable extent [34]. This is indeed the case with base propenals, as demonstrated in studies by Berhane et al. in which GSH added to give a Michael adduct and a substitution product with loss of the nucleobase (Figure 10) [30]. In addition, base propenals were found to be among the best substrates for the Pi class of GSTs, producing a single GSH conjugate (Figure 10).

GSH conjugates have also been identified for furan metabolite cis-1,4-dioxo-2-butene [31, 32], the conformational isomer of the trans-1,4-dioxo-2-butene product of $5^{\prime}$ oxidation (Figure 2). Given the similarity in the reactivity of cis- and trans-1,4-dioxo-2-butene toward DNA adduct formation [9], it would not be surprising to identify 


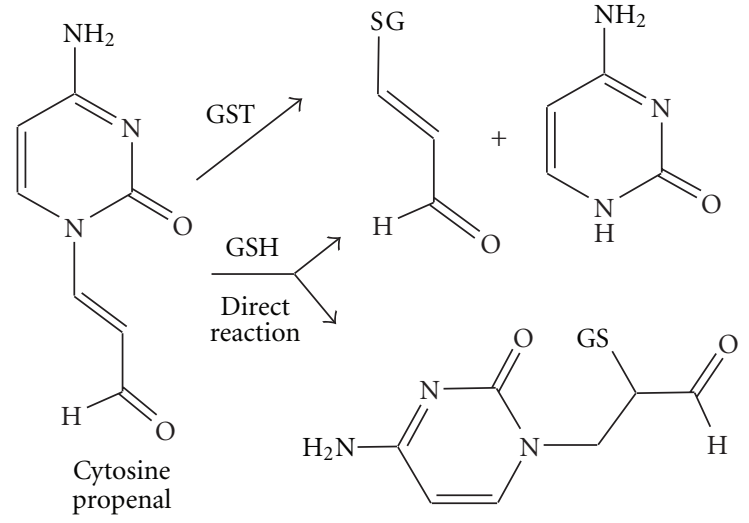<smiles>O=CC=CC(=O)C=CC=O</smiles><smiles>[R]n1cccc1[As]</smiles>

FIGURE 10: Formation of glutathione adducts of 2-deoxyribose oxidation products.

GSH adducts of the trans-isomer product of 2-deoxyribose oxidation, as has been observed in vitro and in vivo with the cis-isomer derivative of furan metabolism $[31,32,112]$.

\section{Prospects}

Molecules damaged during normal physiological processes and in states of pathology represent a large source of biomarkers with potential clinical utility in defining etiological mechanisms, quantifying the risk of human disease and studying interindividual variations in cellular repair pathways. In spite of this potential, there has been little effort to define the biotransformational fate of damaged biomolecules as they move from the site of formation to excretion in clinically accessible compartments. This paper has highlighted examples of this important problem with DNA damage products. Coupled with the development of more sensitive and specific analytical technologies, there are likely to be major advancements in defining the metabolism of DNA damage products and other damaged biomolecules in the coming years.

\section{References}

[1] L. A. Loeb and C. C. Harris, "Advances in chemical carcinogenesis: a historical review and prospective," Cancer Research, vol. 68 , no. 17 , pp. 6863-6872, 2008.
[2] D. E. Barnes and T. Lindahl, "Repair and genetic consequences of endogenous DNA base damage in mammalian cells," Annual Review of Genetics, vol. 38, pp. 445-476, 2004.

[3] J. C. Delaney and J. M. Essigmann, "Biological properties of single chemical-DNA adducts: a twenty year perspective," Chemical Research in Toxicology, vol. 21, no. 1, pp. 232-252, 2008.

[4] G. P. Pfeifer, "Mutagenesis at methylated CpG sequences," Current Topics in Microbiology and Immunology, vol. 301, pp. 259-281, 2006.

[5] R. De Bont and N. van Larebeke, "Endogenous DNA damage in humans: a review of quantitative data," Mutagenesis, vol. 19, no. 3, pp. 169-185, 2004.

[6] B. Epe, "Role of endogenous oxidative DNA damage in carcinogenesis: what can we learn from repair-deficient mice?" Biological Chemistry, vol. 383, no. 3-4, pp. 467-475, 2002.

[7] L. J. Marnett, "Oxyradicals and DNA damage," Carcinogenesis, vol. 21, no. 3, pp. 361-370, 2000.

[8] P. C. Dedon and S. R. Tannenbaum, "Reactive nitrogen species in the chemical biology of inflammation," Archives of Biochemistry and Biophysics, vol. 423, no. 1, pp. 12-22, 2004.

[9] P. C. Dedon, "The chemical toxicology of 2-deoxyribose oxidation in DNA," Chemical Research in Toxicology, vol. 21, no. 1, pp. 206-219, 2008. 
[10] D. Pluskota-Karwatka, "Modifications of nucleosides by endogenous mutagens-DNA adducts arising from cellular processes," Bioorganic Chemistry, vol. 36, no. 4, pp. 198-213, 2008.

[11] Y. Wang, "Bulky DNA lesions induced by reactive oxygen species," Chemical Research in Toxicology, vol. 21, no. 2, pp. 276-281, 2008.

[12] U. Nair, H. Bartsch, and J. Nair, "Lipid peroxidation-induced DNA damage in cancer-prone inflammatory diseases: a review of published adduct types and levels in humans," Free Radical Biology and Medicine, vol. 43, no. 8, pp. 1109-1120, 2007.

[13] S. J. Sturla, "DNA adduct profiles: chemical approaches to addressing the biological impact of DNA damage from small molecules," Current Opinion in Chemical Biology, vol. 11, no. 3, pp. 293-299, 2007.

[14] M. S. Cooke, R. Olinski, and S. Loft, "Measurement and meaning of oxidatively modified DNA lesions in urine," Cancer Epidemiology Biomarkers and Prevention, vol. 17, no. 1, pp. 3-14, 2008.

[15] M. D. Evans, M. Dizdaroglu, and M. S. Cooke, "Oxidative DNA damage and disease: induction, repair and significance," Mutation Research, vol. 567, no. 1, pp. 1-61, 2004.

[16] J. Nair, P. Srivatanakul, C. Haas et al., "High urinary excretion of lipid peroxidation-derived DNA damage in patients with cancer-prone liver diseases," Mutation Research, vol. 683, pp. 23-28, 2009.

[17] S. Dechakhamphu, S. Pinlaor, P. Sitthithaworn, J. Nair, H. Bartsch, and P. Yongvanit, "Lipid peroxidation and etheno DNA adducts in white blood cells of liver fluke-infected patients: protection by plasma $\alpha$-tocopherol and praziquantel," Cancer Epidemiology Biomarkers and Prevention, vol. 19, no. 1, pp. 310-318, 2010.

[18] S. Dechakhamphu, P. Yongvanit, J. Nair, S. Pinlaor, P. Sitthithaworn, and H. Bartsch, "High excretion of etheno adducts in liver fluke-infected patients: protection by Praziquantel against DNA damage," Cancer Epidemiology Biomarkers and Prevention, vol. 17, no. 7, pp. 1658-1664, 2008.

[19] M. Meerang, J. Nair, P. Sirankapracha et al., "Increased urinary $1, N^{6}$-ethenodeoxyadenosine and $3, N^{4}$ ethenodeoxycytidine excretion in thalassemia patients: markers for lipid peroxidation-induced DNA damage," Free Radical Biology and Medicine, vol. 44, no. 10, pp. 1863-1868, 2008.

[20] H.-J. C. Chen and C.-F. Kao, "Effect of gender and cigarette smoking on urinary excretion of etheno DNA adducts in humans measured by isotope dilution gas chromatography/mass spectrometry," Toxicology Letters, vol. 169, no. 1, pp. 72-81, 2007.

[21] P. R. Hillestrøm, M.-I. Covas, and H. E. Poulsen, "Effect of dietary virgin olive oil on urinary excretion of etheno-DNA adducts," Free Radical Biology and Medicine, vol. 41, no. 7, pp. 1133-1138, 2006.

[22] J. Son, B. Pang, J. L. McFaline, K. Taghizadeh, and P. C. Dedon, "Surveying the damage: the challenges of developing nucleic acid biomarkers of inflammation," Molecular BioSystems, vol. 4, no. 9, pp. 902-908, 2008.

[23] M. D. Evans, R. Olinski, S. Loft et al., "Toward consensus in the analysis of urinary 8-oxo-7,8-dihydro- $2^{\prime}$ - deoxyguanosine as a noninvasive biomarker of oxidative stress," FASEB Journal, vol. 24, no. 4, pp. 1249-1260, 2010.
[24] G. B. Elion, A. Kovensky, G. H. Hitchings, E. Metz, and R. W. Rundles, "Metabolic studies of allopurinol, an inhibitor of xanthine oxidase," Biochemical Pharmacology, vol. 15, no. 7, pp. 863-880, 1966.

[25] S. K. Roy, K. R. Korzekwa, F. J. Gonzalez, R. C. Mosche, and M. E. Dolan, "Human liver oxidative metabolism of $O^{6}$ benzylguanine," Biochemical Pharmacology, vol. 50, no. 9, pp. 1385-1389, 1995.

[26] D.-H. Kim and F. P. Guengerich, "Excretion of the mercapturic acid S-[2-( $N^{7}$-guanyl $)$ ethyl $] \mathrm{N}$-acetylcysteine in urine following administration of ethylene dibromide to rats," Cancer Research, vol. 49, no. 21, pp. 5843-5847, 1989.

[27] M. B. Otteneder, C. G. Knutson, J. S. Daniels et al., "In vivo oxidative metabolism of a major peroxidation-derived DNA adduct, M1dG," Proceedings of the National Academy of Sciences of the United States of America, vol. 103, no. 17, pp. 6665-6669, 2006.

[28] C. G. Knutson, D. Akingbade, B. C. Crews, M. Voehler, D. F. Stec, and L. J. Marnett, "Metabolism in vitro and in vivo of the DNA base adduct, $\mathrm{M}_{1} \mathrm{G}$," Chemical Research in Toxicology, vol. 20, no. 3, pp. 550-557, 2007.

[29] C. G. Knutson, P. L. Skipper, R. G. Liberman, S. R. Tannenbaum, and L. J. Marnett, "Monitoring in vivo metabolism and elimination of the endogenous DNA adduct, $\mathrm{M}_{1} \mathrm{dG}$ 3-(2Deoxy- $\beta$-D-erythropentofuranosyl)pyrimido $[1,2-\alpha]$ purin$10(3 H)$-one, by accelerator mass spectrometry," Chemical Research in Toxicology, vol. 21, no. 6, pp. 1290-1294, 2008.

[30] K. Berhane, M. Widersten, A. Engström, J. W. Kozarich, and B. Mannervik, "Detoxication of base propenals and other $\alpha, \beta$-unsaturated aldehyde products of radical reactions and lipid peroxidation by human glutathione transferases," Proceedings of the National Academy of Sciences of the United States of America, vol. 91, no. 4, pp. 1480-1484, 1994.

[31] L.-J. Chen, S. S. Hecht, and L. A. Peterson, "Characterization of amino acid and glutathione adducts of cis-2-butene- 1,4dial, a reactive metabolite of furan," Chemical Research in Toxicology, vol. 10, no. 8, pp. 866-874, 1997.

[32] L. A. Peterson, M. E. Cummings, C. C. Vu, and B. A. Matter, "Glutathione trapping to measure microsomal oxidation of furan to cis-2-butene-1,4-dial," Drug Metabolism and Disposition, vol. 33, no. 10, pp. 1453-1458, 2005.

[33] A. F. Nassar and P. F. H. JoAnn Scatina, Drug Metabolism Handbook, John Wiley \& Sons, River Street Hoboken, NJ, USA, 2009.

[34] L. J. Casarett, J. Doull, and C. D. Klaassen, Casarett and Doull's Toxicology: The Basic Science of Poisons, McGraw-Hill, New York, NY, USA, 7th edition, 2008.

[35] J. Cadet, T. Douki, and J.-L. Ravanat, "Oxidatively generated damage to the guanine moiety of DNA: mechanistic aspects and formation in cells," Accounts of Chemical Research, vol. 41, no. 8, pp. 1075-1083, 2008.

[36] M. S. Cooke, P. T. Henderson, and M. D. Evans, "Sources of extracellular, oxidatively-modified DNA lesions: implications for their measurement in urine," Journal of Clinical Biochemistry and Nutrition, vol. 45, no. 3, pp. 255-270, 2009.

[37] J. C. Niles, J. S. Wishnok, and S. R. Tannenbaum, "Peroxynitrite-induced oxidation and nitration products of guanine and 8-oxoguanine: structures and mechanisms of product formation," Nitric Oxide, vol. 14, no. 2, pp. 109-121, 2006.

[38] J. Cadet, T. Douki, and J.-L. Ravanat, "One-electron oxidation of DNA and inflammation processes," Nature Chemical Biology, vol. 2, no. 7, pp. 348-349, 2006. 
[39] S. Steenken and S. V. Jovanovic, "How easily oxidizable is DNA? One-electron reduction potentials of adenosine and guanosine radicals in aqueous solution," Journal of the American Chemical Society, vol. 119, no. 3, pp. 617-618, 1997.

[40] M. K. Shigenaga, E. N. Aboujaoude, Q. Chen, and B. N. Ames, "Assays of oxidative DNA damage biomarkers 8-oxo2 -deoxyguanosine and 8- oxoguanine in nuclear DNA and biological fluids by high-performance liquid chromatography with electrochemical detection," Methods in Enzymology, vol. 234, pp. 16-33, 1994.

[41] K. Broedbaek, H. E. Poulsen, A. Weimann et al., "Urinary excretion of biomarkers of oxidatively damaged DNA and RNA in hereditary hemochromatosis," Free Radical Biology and Medicine, vol. 47, no. 8, pp. 1230-1233, 2009.

[42] Y. Nakabeppu, S. Oka, Z. Sheng, D. Tsuchimoto, and K. Sakumi, "Programmed cell death triggered by nucleotide pool damage and its prevention by Mut T homolog-1 (MTH1) with oxidized purine nucleoside triphosphatase," Mutation Research, vol. 703, no. 1, pp. 51-58, 2010.

[43] A. G. McLennan, "The Nudix hydrolase superfamily," Cellular and Molecular Life Sciences, vol. 63, no. 2, pp. 123-143, 2006.

[44] T. Paz-Elizur, Z. Sevilya, Y. Leitner-Dagan, D. Elinger, L. C. Roisman, and Z. Livneh, "DNA repair of oxidative DNA damage in human carcinogenesis: potential application for cancer risk assessment and prevention," Cancer Letters, vol. 266, no. 1, pp. 60-72, 2008.

[45] S. Maynard, S. H. Schurman, C. Harboe, N. C. de SouzaPinto, and V. A. Bohr, "Base excision repair of oxidative DNA damage and association with cancer and aging," Carcinogenesis, vol. 30, no. 1, pp. 2-10, 2009.

[46] J. I. Friedman and J. T. Stivers, "Detection of damaged DNA bases by DNA glycosylase enzymes," Biochemistry, vol. 49, no. 24, pp. 4957-4967, 2010.

[47] S. S. David, V. L. O'Shea, and S. Kundu, "Base-excision repair of oxidative DNA damage," Nature, vol. 447, no. 7147, pp. 941-950, 2007.

[48] D. M. Stanbury, "Reduction potentials involving inorganic free radicals in aqueous solution," Advances in Inorganic Chemistry, vol. 33, no. C, pp. 69-138, 1989.

[49] T. N. Das, T. Dhanasekaran, Z. B. Alfassi, and P. Neta, "Reduction potential of the tert-butylperoxyl radical in aqueous solutions," in Proceedings of the 4th International Conference on Chemical Kinetics, National Institute of Standards and Technology, Gaithersburg, Md, USA, 1997.

[50] J. M. Lee, J. C. Niles, J. S. Wishnok, and S. R. Tannenbaum, "Peroxynitrite reacts with 8-oitropurines to yield 8oxopurines," Chemical Research in Toxicology, vol. 15, no. 1, pp. 7-14, 2002.

[51] R. S. Hall, A. A. Fedorov, R. Marti-Arbona et al., "The hunt for 8-oxoguanine deaminase," Journal of the American Chemical Society, vol. 132, no. 6, pp. 1762-1763, 2010.

[52] M. Dong and P. C. Dedon, "Relatively small increases in the steady-state levels of nucleobase deamination products in DNA from human TK6 cells exposed to toxic levels of nitric oxide," Chemical Research in Toxicology, vol. 19, no. 1, pp. 5057, 2006.

[53] M. Dong, C. Wang, W. M. Deen, and P. C. Dedon, "Absence of 2'-deoxyoxanosine and presence of abasic sites in DNA exposed to nitric oxide at controlled physiological concentrations," Chemical Research in Toxicology, vol. 16, no. 9, pp. 1044-1055, 2003.
[54] B. Pang, X. Zhou, H. Yu et al., "Lipid peroxidation dominates the chemistry of DNA adduct formation in a mouse model of inflammation," Carcinogenesis, vol. 28, no. 8, pp. 1807-1813, 2007.

[55] K. Taghizadeh, J. L. McFaline, B. Pang et al., "Quantification of DNA damage products resulting from deamination, oxidation and reaction with products of lipid peroxidation by liquid chromatography isotope dilution tandem mass spectrometry," Nature Protocols, vol. 3, no. 8, pp. 1287-1298, 2008.

[56] L. J. Marnett, "Oxy radicals, lipid peroxidation and DNA damage,” Toxicology, vol. 181-182, pp. 219-222, 2002.

[57] T. J. Montine, M. D. Neely, J. F. Quinn et al., "Lipid peroxidation in aging brain and Alzheimer's disease," Free Radical Biology and Medicine, vol. 33, no. 5, pp. 620-626, 2002.

[58] H. Bartsch and J. Nair, "Oxidative stress and lipid peroxidation-derived DNA-lesions in inflammation driven carcinogenesis," Cancer Detection and Prevention, vol. 28, no. 6, pp. 385-391, 2004.

[59] M. V. Williams, H. L. Seon, M. Pollack, and I. A. Blair, "Endogenous lipid hydroperoxide-mediated DNA-adduct formation in min mice," The Journal of Biological Chemistry, vol. 281, no. 15, pp. 10127-10133, 2006.

[60] S. H. Lee, M. V. Williams, R. N. DuBois, and I. A. Blair, "Cyclooxygenase-2-mediated DNA damage," The Journal of Biological Chemistry, vol. 280, no. 31, pp. 28337-28346, 2005.

[61] K. Schmid, J. Nair, G. Winde, I. Velic, and H. Bartsch, "Increased levels of promutagenic etheno-DNA adducts in colonic polyps of FAP patients," International Journal of Cancer, vol. 87, no. 1, pp. 1-4, 2000.

[62] J. Nair, A. Barbin, and H. Bartsch, "Etheno DNAbase adducts from endogenous reactive species," Mutation Research, vol. 424, no. 1-2, pp. 59-69, 1999.

[63] S. H. Lee, J. A. Arora, T. Oe, and I. A. Blair, "4-Hydroperoxy-2-nonenal-induced formation of $1, \mathrm{~N}^{2}$-etheno- $2^{\prime}$-deoxyguanosine adducts," Chemical Research in Toxicology, vol. 18, no. 4, pp. 780-786, 2005.

[64] H.-J.C. Chen, G.-J. Lin, and W.-P. Lin, "Simultaneous quantification of three lipid peroxidation-derived etheno adducts in human DNA by stable isotope dilution nanoflow liquid chromatography nanospray ionization tandem mass spectrometry," Analytical Chemistry, vol. 82, no. 11, pp. 4486-4493, 2010.

[65] L. Gros, A. A. Ishchenko, and M. Saparbaev, "Enzymology of repair of etheno-adducts," Mutation Research, vol. 531, no. 1-2, pp. 219-229, 2003.

[66] C. G. Knutson, E. H. Rubinson, D. Akingbade et al., "Oxidation and glycolytic cleavage of etheno and propano DNA base adducts," Biochemistry, vol. 48, no. 4, pp. 800-809, 2009.

[67] X. Zhou, K. Taghizadeh, and P. C. Dedon, "Chemical and biological evidence for base propenals as the major source of the endogenous $\mathrm{M}_{1} \mathrm{dG}$ adduct in cellular DNA," The Journal of Biological Chemistry, vol. 280, no. 27, pp. 25377-25382, 2005.

[68] P. C. Dedon, J. P. Plastaras, C. A. Rouzer, and L. J. Marnett, "Indirect mutagenesis by oxidative DNA damage: formation of the pyrimidopurinone adduct of deoxyguanosine by base propenal," Proceedings of the National Academy of Sciences of the United States of America, vol. 95, no. 19, pp. 11113-11116, 1998. 
[69] J. P. Plastaras, J. N. Riggins, M. Otteneder, and L. J. Marnett, "Reactivity and mutagenicity of endogenous DNA oxopropenylating agents: base propenals, malondialdehyde, and $N^{\varepsilon}$-oxopropenyllysine," Chemical Research in Toxicology, vol. 13, no. 12, pp. 1235-1242, 2000.

[70] A. K. Basu, S. M. O’Hara, P. Valladier, K. Stone, O. Mols, and L. J. Marnett, "Identification of adducts formed by reaction of guanine nucleosides with malondialdehyde and structurally related aldehydes," Chemical Research in Toxicology, vol. 1, no. 1, pp. 53-59, 1988.

[71] A. K. Chaudhary, M. Nokubo, G. R. Reddy et al., "Detection of endogenous malondialdehyde-deoxyguanosine adducts in human liver," Science, vol. 265, no. 5178, pp. 1580-1582, 1994.

[72] Y.-C. Jeong and J. A. Swenberg, "Formation of $\mathrm{M}_{1} \mathrm{G}-\mathrm{dR}$ from endogenous and exogenous ROS-inducing chemicals," Free Radical Biology and Medicine, vol. 39, no. 8, pp. 1021-1029, 2005.

[73] C. A. Rouzer, A. K. Chaudhary, M. Nokubo et al., "Analysis of the malondialdehyde- 2 '-deoxyguanosine adduct pyrimidopurinone in human leukocyte DNA by gas chromatography/electron capture/negative chemical ionization/mass spectrometry," Chemical Research in Toxicology, vol. 10, no. 2, pp. 181-188, 1997.

[74] A. K. Chaudhary, G. R. Reddy, I. A. Blair, and L. J. Marnett, "Characterization of an $N^{6}$-oxopropenyl-2'-deoxyadenosine adduct in malondialdehyde-modified DNA using liquid chromatography/electrospray ionization tandem mass spectrometry," Carcinogenesis, vol. 17, no. 5, pp. 1167-1170, 1996.

[75] Y.-C. Jeong, R. Sangaiah, J. Nakamura et al., "Analysis of $\mathrm{M}_{1} \mathrm{G}-\mathrm{dR}$ in DNA by aldehyde reactive probe labeling and liquid chromatography tandem mass spectrometry," Chemical Research in Toxicology, vol. 18, no. 1, pp. 51-60, 2005.

[76] F. F. Kadlubar, K. E. Anderson, S. Häussermann et al., "Comparison of DNA adduct levels associated with oxidative stress in human pancreas," Mutation Research, vol. 405, no. 2, pp. 125-133, 1998.

[77] C. Leuratti, R. Singh, C. Lagneau et al., "Determination of malondialdehyde-induced DNA damage in human tissues using an immunoslot blot assay," Carcinogenesis, vol. 19, no. 11, pp. 1919-1924, 1998.

[78] P. Yi, X. Sun, D. R. Doerge, and P. P. Fu, "An improved 32P-postlabeling/high-performance liquid chromatography method for the analysis of the malondialdehye-derived $1, N^{6}$ propanodeoxyguanosine DNA adduct in animal and human tissues," Chemical Research in Toxicology, vol. 11, no. 9, pp. 1032-1041, 1998.

[79] A.-M. Hoberg, M. Otteneder, L. J. Marnett, and H. E. Poulsen, "Measurement of the malondialdehyde-2'-deoxyguanosine adduct in human urine by immuno-extraction and liquid chromatography/atmospheric pressure chemical ionization tandem mass spectrometry," Journal of Mass Spectrometry, vol. 39, no. 1, pp. 38-42, 2004.

[80] S. P. Fink, G. R. Reddy, and L. J. Marnett, "Mutagenicity in Escherichia coli of the major DNA adduct derived from the endogenous mutagen malondialdehyde," Proceedings of the National Academy of Sciences of the United States of America, vol. 94, no. 16, pp. 8652-8657, 1997.

[81] L. J. Marnett, "Lipid peroxidation-DNA damage by malondialdehyde," Mutation Research, vol. 424, no. 1-2, pp. 83-95, 1999.
[82] A. Weimann, D. Belling, and H. E. Poulsen, "Quantification of 8-oxo-guanine and guanine as the nucleobase, nucleoside and deoxynucleoside forms in human urine by highperformance liquid chromatography-electrospray tandem mass spectrometry," Nucleic acids research, vol. 30, no. 2, p. E7, 2002.

[83] M. Awada and P. C. Dedon, "Formation of the $1, N^{2}$-glyoxal adduct of deoxyguanosine by phosphoglycolaldehyde, a product of $3^{\prime}$-deoxyribose oxidation in DNA," Chemical Research in Toxicology, vol. 14, no. 9, pp. 1247-1253, 2001.

[84] G. A. Lahoud, A. L. Hitt, and A. C. Bryant-Friedrich, "Aerobic fate of the C-3' -thymidinyl radical in single-stranded DNA," Chemical Research in Toxicology, vol. 19, no. 12, pp. 16301636, 2006.

[85] H. Sugiyama, Y. Tsutsumi, K. Fujimoto, and I. Saito, "Photoinduced deoxyribose $\mathrm{C} 2^{\prime}$ oxidation in DNA. Alkalidependent cleavage of erythrose-containing sites via a retroaldol reaction," Journal of the American Chemical Society, vol. 115, no. 11, pp. 4443-4448, 1993.

[86] J. Kim, Y. N. Weledji, and M. M. Greenberg, "Independent generation and characterization of a $\mathrm{C}^{2}$ '-oxidized abasic site in chemically synthesized oligonucleotides," Journal of Organic Chemistry, vol. 69, no. 18, pp. 6100-6104, 2004.

[87] T. Bohnert, L. Gingipalli, and P. C. Dedon, "Reaction of 2 -deoxyribonucleosides with cis- and trans-1,4-dioxo-2butene," Biochemical and Biophysical Research Communications, vol. 323, no. 3, pp. 838-844, 2004.

[88] B. Chen, T. Bohnert, X. Zhou, and P. C. Dedon, " 5 '-(2phosphoryl-1,4-dioxobutane) as a product of $5^{\prime}$-oxidation of deoxyribose in DNA: elimination as trans-1,4-dioxo-2butene and approaches to analysis," Chemical Research in Toxicology, vol. 17, no. 11, pp. 1406-1413, 2004.

[89] B. Chen, C. C. Vu, M. C. Byrns, P. C. Dedon, and L. A. Peterson, "Formation of 1,4-dioxo-2-butene-derived adducts of 2 -deoxyadenosine and 2'-deoxycytidine in oxidized DNA," Chemical Research in Toxicology, vol. 19, no. 8, pp. 982-985, 2006.

[90] M. C. Byrns, D. P. Predecki, and L. A. Peterson, "Characterization of nucleoside adducts of cis-2-butene-1,4-dial, a reactive metabolite of furan," Chemical Research in Toxicology, vol. 15, no. 3, pp. 373-379, 2002.

[91] M. C. Byrns, C. C. Vu, J. W. Neidigh, J.-L. Abad, R. A. Jones, and L. A. Peterson, "Detection of DNA adducts derived from the reactive metabolite of furan, cis-2-butene-1,4-dial," Chemical Research in Toxicology, vol. 19, no. 3, pp. 414-420, 2006.

[92] M. Hashimoto, M. M. Greenberg, Y. W. Kow, J.-T. Hwang, and R. P. Cunningham, "The 2-deoxyribonolactone lesion produced in DNA by neocarzinostatin and other damaging agents forms cross-links with the base-excision repair enzyme endonuclease III," Journal of the American Chemical Society, vol. 123, no. 13, pp. 3161-3162, 2001.

[93] M. S. Demott, E. Beyret, D. Wong et al., "Covalent trapping of human DNA polymerase $\beta$ by the oxidative DNA lesion 2-deoxyribonolactone," The Journal of Biological Chemistry, vol. 277, no. 10, pp. 7637-7640, 2002.

[94] S. Boiteux, "Properties and biological functions of the NTH and FPG proteins of Escherichia coli: two DNA glycosylases that repair oxidative damage in DNA," Journal of Photochemistry and Photobiology B, vol. 19, no. 2, pp. 87-96, 1993.

[95] Y. Zheng and T. L. Sheppard, "Half-life and DNA strand scission products of 2-deoxyribonolactone oxidative DNA damage lesions," Chemical Research in Toxicology, vol. 17, no. 2, pp. 197-207, 2004. 
[96] R. M. LoPachin, T. Gavin, D. R. Petersen, and D. S. Barber, "Molecular mechanisms of 4-hydroxy-2-nonenal and acrolein toxicity: nucleophilic targets and adduct formation," Chemical Research in Toxicology, vol. 22, no. 9, pp. 1499-1508, 2009.

[97] A. K. Yocum, T. Oe, A. L. Yergey, and I. A. Blair, "Novel lipid hydroperoxide-derived hemoglobin histidine adducts as biomarkers of oxidative stress," Journal of Mass Spectrometry, vol. 40, no. 6, pp. 754-764, 2005.

[98] L. M. Sayre, D. A. Zelasko, P. L. R. Harris, G. Perry, R. G. Salomon, and M. A. Smith, "4-Hydroxynonenal-derived advanced lipid peroxidation end products are increased in Alzheimer's disease," Journal of Neurochemistry, vol. 68, no. 5, pp. 2092-2097, 1997.

[99] M. Hashimoto, T. Sibata, H. Wasada, S. Toyokuni, and K. Uchida, "Structural basis of protein-bound endogenous aldehydes: chemical and immunochemical characterizations of configurational isomers of a 4-hydroxy-2-nonenalhistidine adduct," The Journal of Biological Chemistry, vol. 278, no. 7, pp. 5044-5051, 2003.

[100] T. Ishii, S. Kumazawa, T. Sakurai, T. Nakayama, and K. Uchida, "Mass spectroscopic characterization of protein modification by malondialdehyde," Chemical Research in Toxicology, vol. 19, no. 1, pp. 122-129, 2006.

[101] W. Siems and T. Grune, "Intracellular metabolism of 4hydroxynonenal," Molecular Aspects of Medicine, vol. 24, no. 4-5, pp. 167-175, 2003.

[102] D. L. Carbone, J. A. Doorn, Z. Kiebler, B. R. Ickes, and D. R. Petersen, "Modification of heat shock protein 90 by 4-hydroxynonenal in a rat model of chronic alcoholic liver disease," Journal of Pharmacology and Experimental Therapeutics, vol. 315, no. 1, pp. 8-15, 2005.

[103] S. Yamada, T. Funada, N. Shibata et al., "Proteinbound 4-hydroxy-2-hexenal as a marker of oxidized n-3 polyunsaturated fatty acids," Journal of Lipid Research, vol. 45, no. 4, pp. 626-634, 2004.

[104] W.-H. Zhang, J. Liu, G. Xu, Q. Yuan, and L. M. Sayre, "Model studies on protein side chain modification by 4-Oxo-2-nonenal," Chemical Research in Toxicology, vol. 16, no. 4, pp. 512-523, 2003.

[105] G. A. Nacheva, D. Y. Guschin, O. V. Preobrazhenskaya, V. L. Karpov, K. K. Ebralidse, and A. D. Mirzabekov, "Change in the pattern of histone binding to DNA upon transcriptional activation," Cell, vol. 58, no. 1, pp. 27-36, 1989.

[106] K. K. Ebralidse, S. A. Grachev, and A. D. Mirzabekov, "A highly basic histone $\mathrm{H} 4$ domain bound to the sharply bent region of nucleosomal DNA," Nature, vol. 331, no. 6154, pp. 365-367, 1988.

[107] D. A. Slatter, C. H. Bolton, and A. J. Bailey, "The importance of lipid-derived malondialdehyde in diabetes mellitus," Diabetologia, vol. 43, no. 5, pp. 550-557, 2000.

[108] D. A. Slatter, N. C. Avery, and A. J. Bailey, "Identification of a new cross-link and unique histidine adduct from bovine serum albumin incubated with malondialdehyde," The Journal of Biological Chemistry, vol. 279, no. 1, pp. 61-69, 2004.

[109] T. Jiang, X. Zhou, K. Taghizadeh, M. Dong, and P. C. Dedon, "N-formylation of lysine in histone proteins as a secondary modification arising from oxidative DNA damage," Proceedings of the National Academy of Sciences of the United States of America, vol. 104, no. 1, pp. 60-65, 2007.

[110] P. Close, C. Creppe, M. Gillard et al., "The emerging role of lysine acetylation of non-nuclear proteins," Cellular and Molecular Life Sciences, vol. 67, no. 8, pp. 1255-1264, 2010.
[111] X.-J. Yang and E. Seto, "Lysine acetylation: codified crosstalk with other posttranslational modifications," Molecular Cell, vol. 31, no. 4, pp. 449-461, 2008.

[112] L. A. Peterson, K. C. Naruko, and D. P. Predecki, "A reactive metabolite of furan, cis-2-butene-1,4-dial, is mutagenic in the Ames assay," Chemical Research in Toxicology, vol. 13, no. 7, pp. 531-534, 2000. 

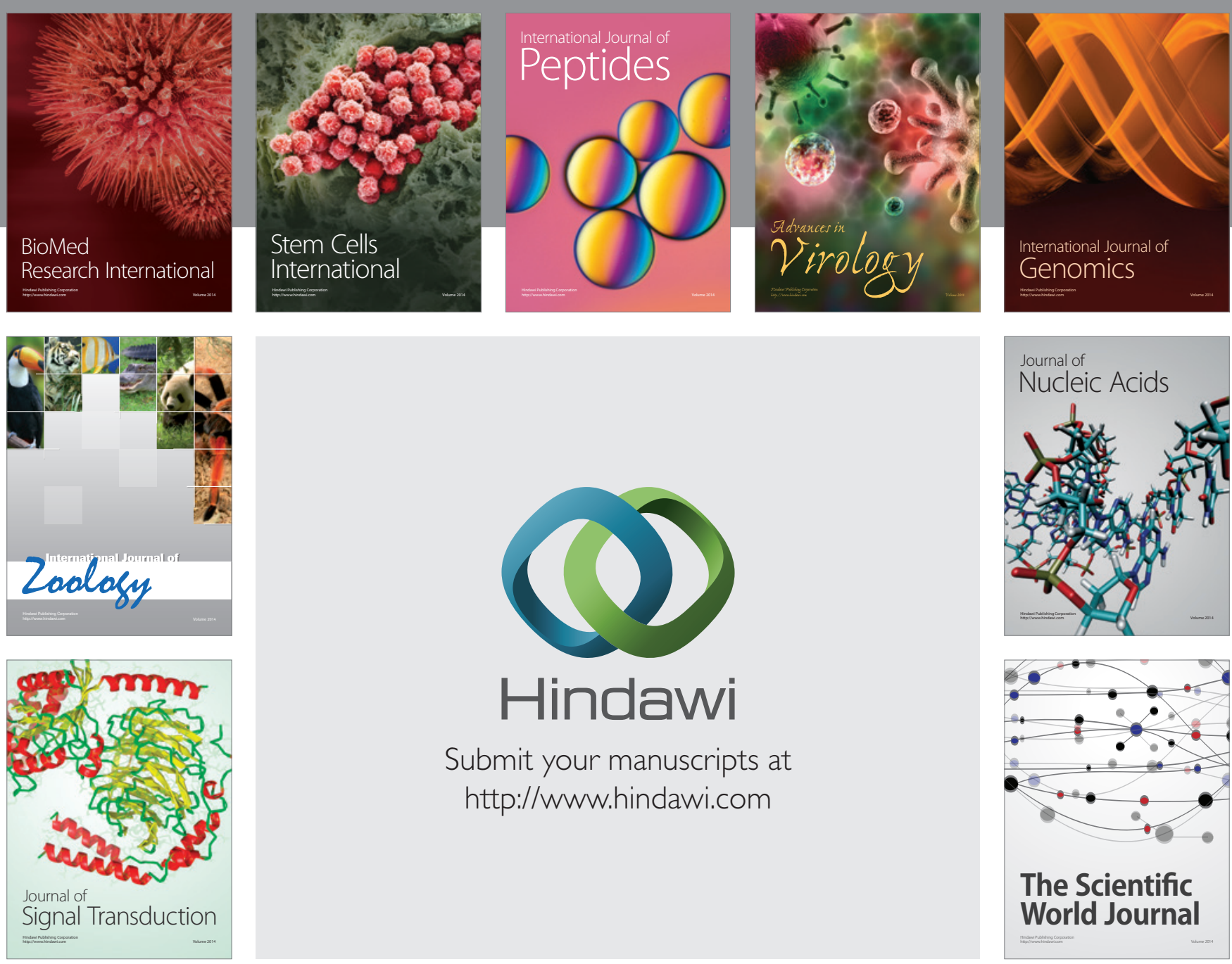

Submit your manuscripts at

http://www.hindawi.com
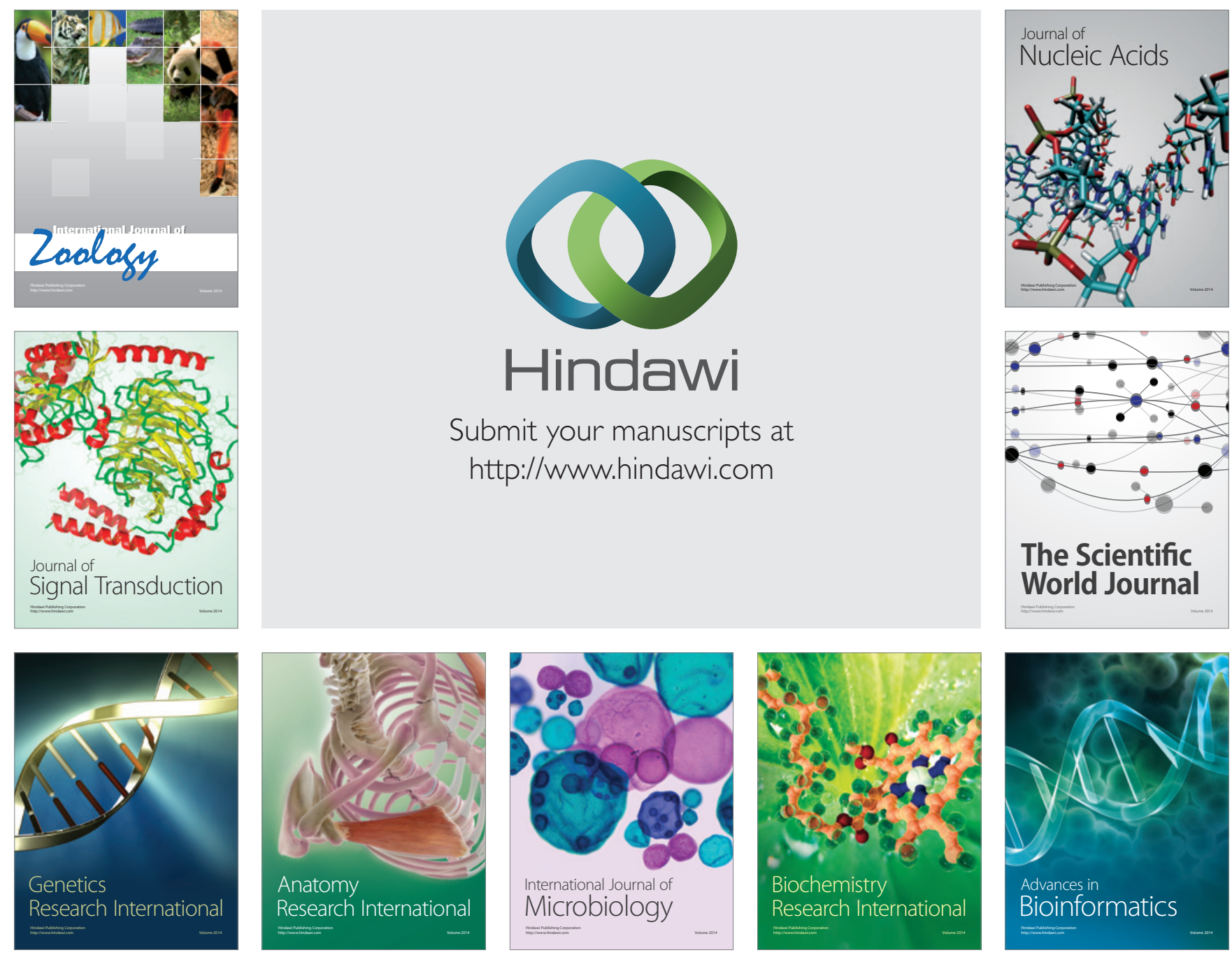

The Scientific World Journal
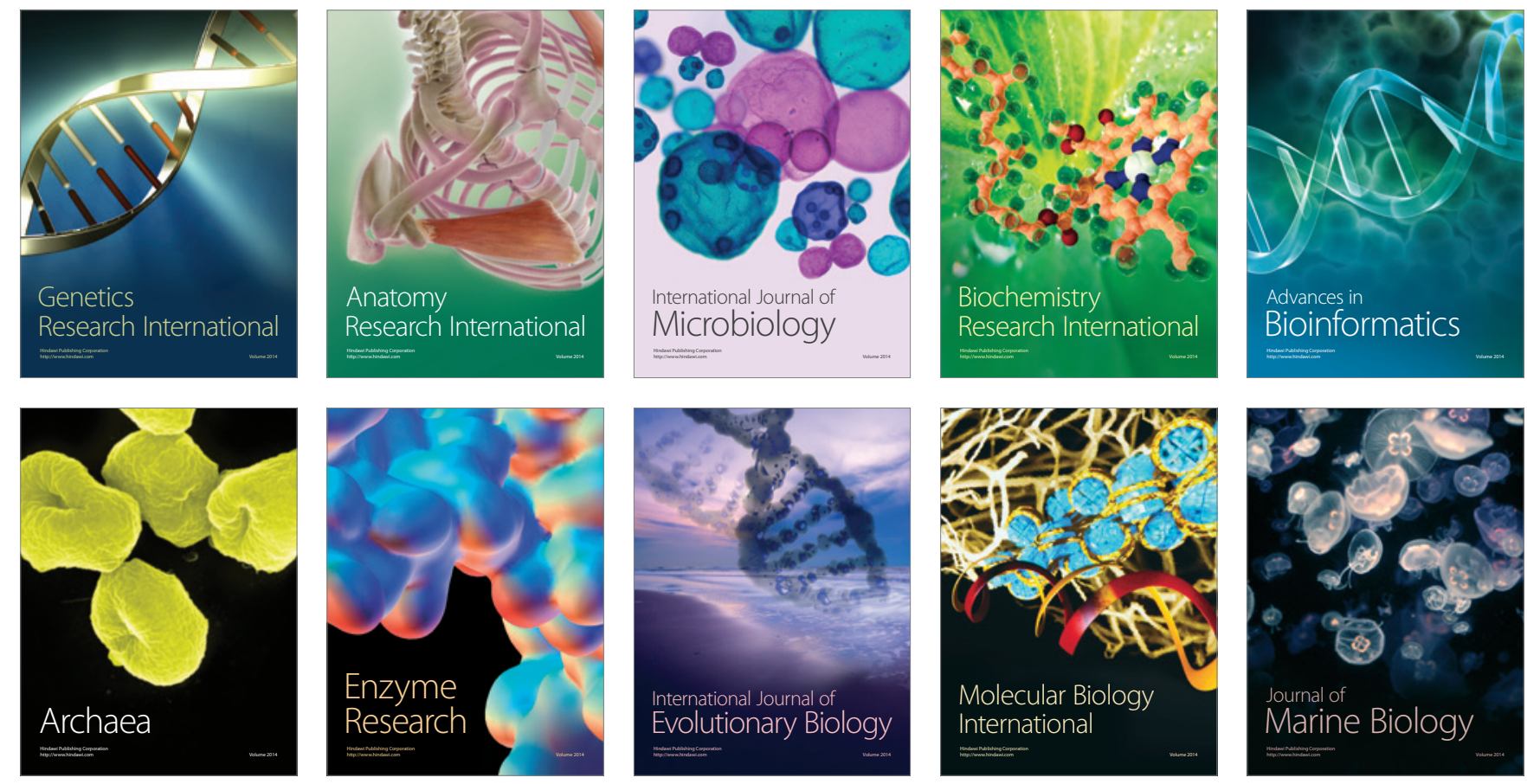